\title{
OPTIMIZATION OF GREEN SYNTHESIZED SILVER NANOPARTICLES FROM CARALLUMA UMBELLATA
}

\section{ANJU K., ANITHA JEGADEESHWARI L., NAGENDRA GANDHI N. *}

\author{
Department of Chemical Engineering, ACT Campus, Anna University, Chennai 600025, Tamil Nadu, India
}

Email: nagendragandhi.n@gmail.com

Received: 25 Apr 2018, Revised and Accepted: 24 May 2018

\section{ABSTRACT}

Objective: The current study focuses on optimization and ecologically innocuous green synthesis of silver nanoparticles (AgNPs) using tribal plant Caralluma umbellata and to study its potential as an antibacterial and antifungal agent.

Methods: The synthesis of AgNPs were confirmed by the colour change of the stem extract from yellow to dark brown and by UV-Visible spectroscopy. The optimum conditions for synthesis of AgNPs were analysed using Response surface methodology (RSM) based Box-Behnken design (BBD) using Design Expert software (7.0.0 trial version). The AgNPs synthesized were characterized by Scanning electron microscope (SEM), Energy dispersive X-ray (EDX), Fourier transform infrared (FTIR) and X-ray diffraction (XRD) analysis. Further, antibacterial and antifungal activity were performed using well diffusion method for both plant extract and AgNPs.

Results: The UV-Visible spectrum of AgNPs revealed characteristic peak at $425.5 \mathrm{~nm}$. The crystalline nature of synthesized AgNPs was confirmed by XRD with average size $26 \mathrm{~nm}$. SEM confirms the spherical shape of AgNPs and by EDX the presence of elemental silver was observed. The ability of the plant to produce both reducing and capping agents were confirmed by FTIR. The optimum conditions for synthesis of AgNPs were found to be $0.55 \mathrm{mmol} \mathrm{AgNO}_{3}$ concentration, $45^{\circ} \mathrm{C}$ temperature and $24 \mathrm{~h}$ reaction time. Both plant sample and synthesized AgNPs exhibited good antimicrobial activity where AgNPs showed superior efficacy as an antimicrobial agent over the other.

Conclusion: From the results obtained, it can be deduced that both $C$. umbellata stem extract and synthesized AgNPs can act as potent antimicrobial agent. But the synthesized AgNPs is more potent against bacteria and fungus.

Keywords: Nanomedicine, Silver nanoparticles, Tribal plant, BBD, Antimicrobial agent

(C) 2018 The Authors. Published by Innovare Academic Sciences Pvt Ltd. This is an open access article under the CC BY license (http://creativecommons.org/licenses/by/4.0/) DOI: http://dx.doi.org/10.22159/ijap.2018v10i4.26928

\section{INTRODUCTION}

Nanoparticles have allured medicine and other fields due to its outstanding physical, chemical and biological properties [1]. Here, the nanodrugs act as carriers to improve the drug distribution to the targeted site by protecting the healthy cells [2]. The metal silver in the form of Rajata Bhasma had its attention from traditional medicine and is known to elevate the immune response [3]. Silver in the form of nanoparticles (AgNPs) are noble metals where their large surface area gives enhanced antimicrobial activity [4]. This exceptional property of silver has made its availability especially in biomedical industry and almost in all consumer products [5]. Plant-mediated green synthesis of AgNPs can be synthesized in a lucrative and eco-friendly manner [6] by replacing chemically derived reducing and capping agents with plants phytochemicals [7, 8], whereas the other methods tends releases noxious chemicals to the environment [9]. Also, plants efficacy can be increased by synthesizing AgNPs from its parts [10].

In this present study, the silver nanoparticles are synthesized from the tribal plant Caralluma umbellata (fig. 1) of family Asclepiadaceae. C. umbellata is the ground-dwelling, succulent, xerophytic herb consisting of two parts-root and thornless stem [11]. Due to the presence of various phytochemicals and diverse therapeutic properties, C. umbellata is used to treat stomach ache and gastric ulcers by Kanni and Yanadi tribes of Tamil Nadu and Andhra Pradesh respectively $[12,13]$, the ethanolic extracts of $\mathrm{C}$. umbellata serves as a remedy for liver toxicity [14], methanolic extract of this plant showed promising anti-diabetic activity [15]. Here, AgNPs were synthesized in an optimized route from novel stem extract of $\mathrm{C}$. umbellata and the antimicrobial activity of the synthesized AgNPs (Cu-AgNPs) was compared with the pure stem extract of $\mathrm{C}$. umbellata (Cu-SE).

\section{MATERIALS AND METHODS}

\section{Materials}

Silver nitrate $\left(\mathrm{AgNO}_{3}\right)$ from Fisher Scientific was used. Stems of Caralluma umbellata (AKAJ/MK101/09/2017) was collected in $12.1899^{\circ} \mathrm{N}, 79.9249^{\circ} \mathrm{E}$, Auroville women's nursery (Marakkanam). Nutrient agar, Potato dextrose agar, antibiotic tetracycline and fluconazole, microbial strains E. coli, B. subtilis and A. niger.

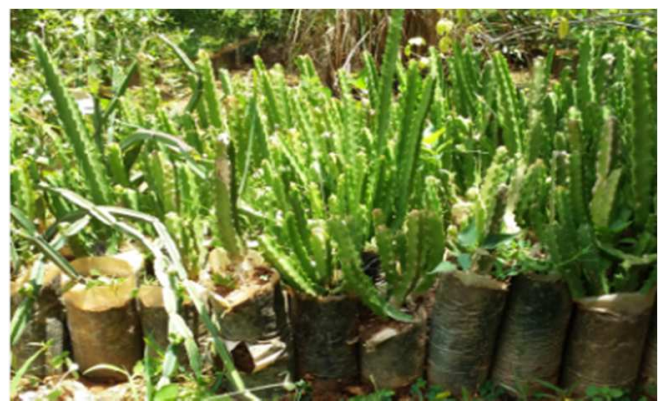

Fig. 1: Tribal plant Caralluma umbellata

\section{Stem extract preparation}

The collected stems of $C$. umbellata was shade dried and grinded to fine powder. To that $5 \mathrm{~g}$ of the powdered mixture, $100 \mathrm{ml}$ of doubledistilled water was added and was heated for $20 \mathrm{~min}$. The pure stem extract was thus obtained by filtering the resulting concoction using whatman filter paper which turned yellow in colour.

\section{Synthesis of silver nanoparticles (AgNPs)}

To the $20 \mathrm{ml}$ of the stem extract prepared, $20 \mathrm{ml}$ of $0.55 \mathrm{mmol}$ silver nitrate solution was added at a regular interval of 5 min (1:1 ratio) and stirred continuously for $20 \mathrm{~min}$ using magnetic stirrer. This resulted in the colour change of the stem extract of $C$. umbellata from yellow to dark brown which signifies the reduction of $\mathrm{Ag}^{+}$ions in the solution to $\mathrm{Ag}^{\circ}$ ions [10]. 
Characterization studies of AgNPs synthesized from stem extract of $C$. umbellata

The synthesized AgNPs absorbance and stability was monitored using UV-Visible spectroscopy. Scanning electron microscopy (SEM) can be used to observe the size and shape of the AgNPs in high resolution. The reducing and capping agent present in the stem extract in the form of phytochemicals were identified by FourierTransform Infrared (FTIR) spectroscopy. The FTIR range was fixed between $500 \mathrm{~cm}^{-1}$ to $4500 \mathrm{~cm}^{-1}$. The X-Ray Diffraction (XRD) analysis were performed over $2 \theta$ range from $20^{\circ}$ to $80^{\circ}$, where the crystal size and structure of the stem extract can be identified. The elemental silver presence along with its percentage of weight can be analysed using Energy Dispersive X-ray (EDX) analysis.

\section{Antibacterial assay}

The bacterial and fungal strains were obtained from The Institute of Microbial Technology, Chandigarh, India. The antibacterial activity was analysed for the $\mathrm{Cu}-\mathrm{SE}$ and $\mathrm{Cu}-\mathrm{AgNPs}$ against gram positive Bacillus subtilis (MTCC 441) and gram negative Escherichia coli (MTCC 739). Well, diffusion assay was prepared by making 5 wells in the solidified nutrient agar swabbed with $24 \mathrm{~h}$ grown culture. With tetracycline as a positive control in the middle well and different concentrations of the test samples $(250 \mu \mathrm{g} / \mathrm{ml}$, $500 \mu \mathrm{g} / \mathrm{ml}, 750 \mu \mathrm{g} / \mathrm{ml}, 1000 \mu \mathrm{g} / \mathrm{ml}$ ) were loaded to the four surrounding wells and incubated at $37{ }^{\circ} \mathrm{C}$ for $24 \mathrm{~h}$. The inhibition zone diameter was measured after incubation to understand its inhibitory action [8].

\section{Antifungal assay}

Antifungal action of varying concentration $(250 \mu \mathrm{g} / \mathrm{ml}, 500 \mu \mathrm{g} / \mathrm{ml}$, $750 \mu \mathrm{g} / \mathrm{ml}, 1000 \mu \mathrm{g} / \mathrm{ml}$ ) of Cu-SE and Cu-AgNPs were tested against Aspergillus niger (MTCC 5889) swabbed onto solidified potato dextrose agar (PDA) medium. Antibiotic fluconazole was used as a positive control. The zone of inhibition was measured after incubation at $37^{\circ} \mathrm{C}$ for $2-3 \mathrm{~d}$ [16].

\section{RESULTS}

\section{RSM optimization}

The optimal conditions for the synthesis of AgNPs were carried out by Response surface methodology (RSM) integrated with Box Behnken Design (BBD) using Design Expert software (7.0.0 trial version). A total of 17 runs were experimentally conducted for the process parameters Silver nitrate $\left(\mathrm{AgNO}_{3}\right)$ concentration $(\mathrm{mM})$, temperature $\left({ }^{\circ} \mathrm{C}\right)$ and incubation time $(\mathrm{min})$. The output responses observed through experiments was in close fit with the model predicted values (fig. 2). Also, p-value Prob $>F$ (0.0001) in ANOVA represents that the model is significant. Using Design expert, the 3D plots (fig. 3a, 3b, 3c) generated predicted the optimal conditions at the maximum absorbance $(0.7398)$ to be $0.55 \mathrm{mmol} \mathrm{AgNO}_{3}$ concentration, $45^{\circ} \mathrm{C}$ and $1442.50 \mathrm{~min}(24 \mathrm{~h})$.

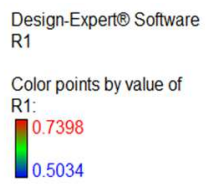

Design Expene Sotware

RI

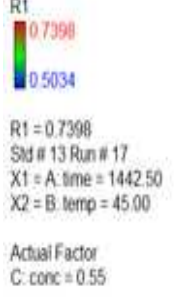

A

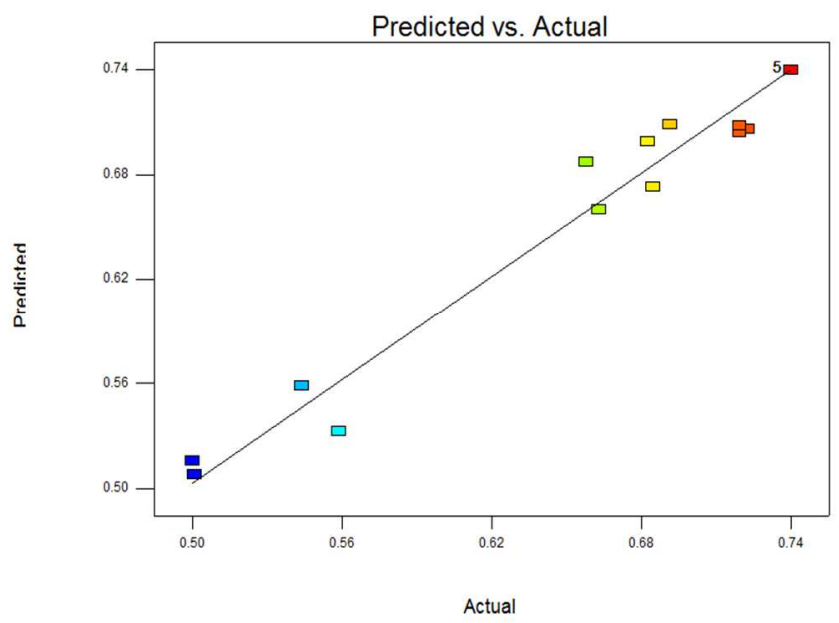

Fig. 2: RSM predicted vs. Actual values

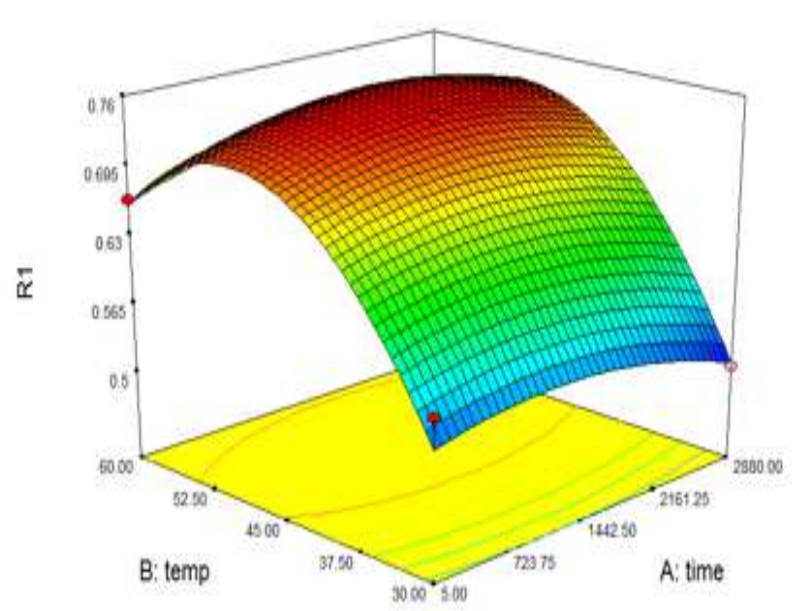




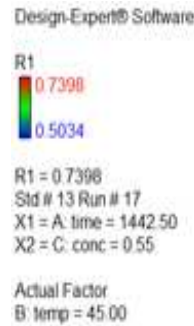

B

$\mathrm{C}$

R1
07396
05034

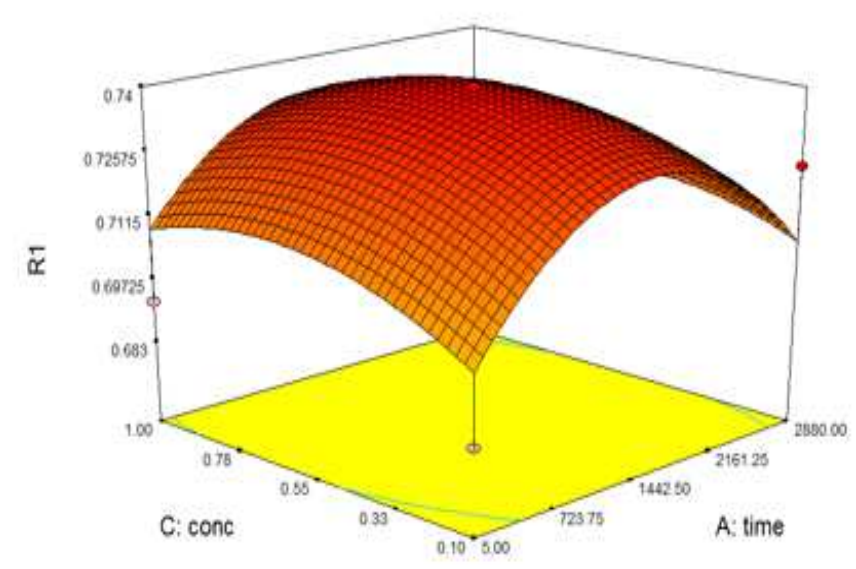

Dessoneipene Sohware

\begin{tabular}{|c|}
\hline 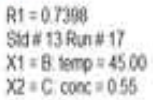 \\
\hline $\begin{array}{l}\text { Actual Fado } \\
\text { A. ame }=144250\end{array}$ \\
\hline
\end{tabular}

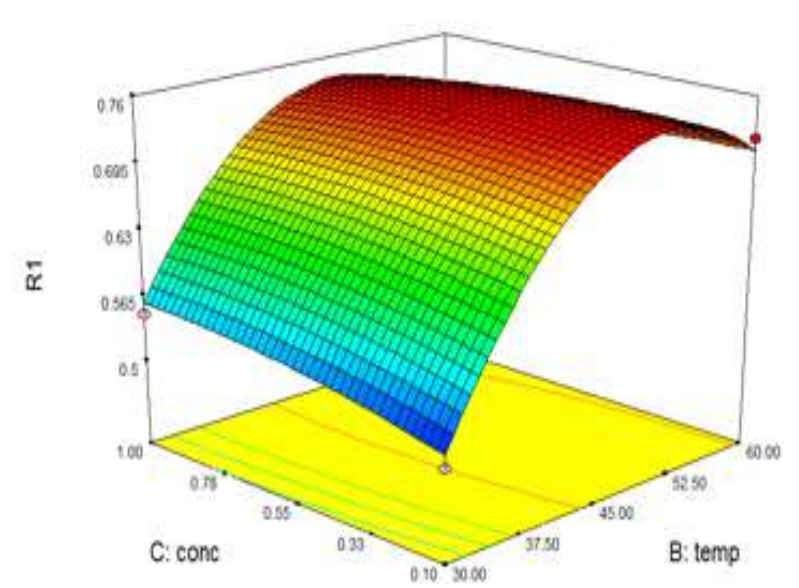

Fig. 3 (A, B, C): 3D plots of the combined effect of two variables on C. umbellata plant-mediated synthesis of AgNPs

\section{UV-Visible spectroscopy}

The AgNPs synthesized from the Cu-SE can be observed visually by the colour change of the extract from yellow (fig. 4a) to dark brown (fig. 4b) on the addition of aqueous silver nitrate $\left(\mathrm{AgNO}_{3}\right)$ solution. The reduction of $\mathrm{Ag}^{+}$ions to $\mathrm{Ag}^{\circ}$ ions by the phytochemicals present in the Cu-SE was initially analyzed by UV-Visible spectroscopy with the absorbance band near $425.5 \mathrm{~nm}$ (fig. 5).
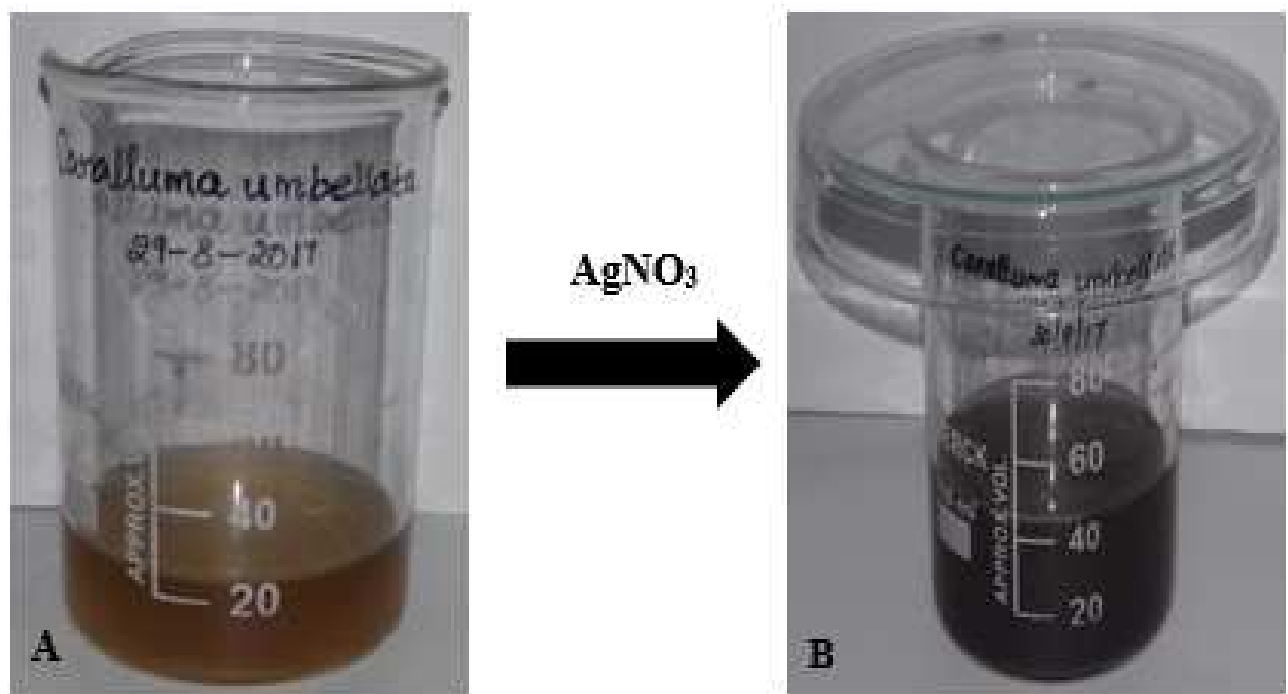

Fig. 4: Colour change of Cu-SE from (A) yellow to (B) dark brown (Cu-AgNPs) 


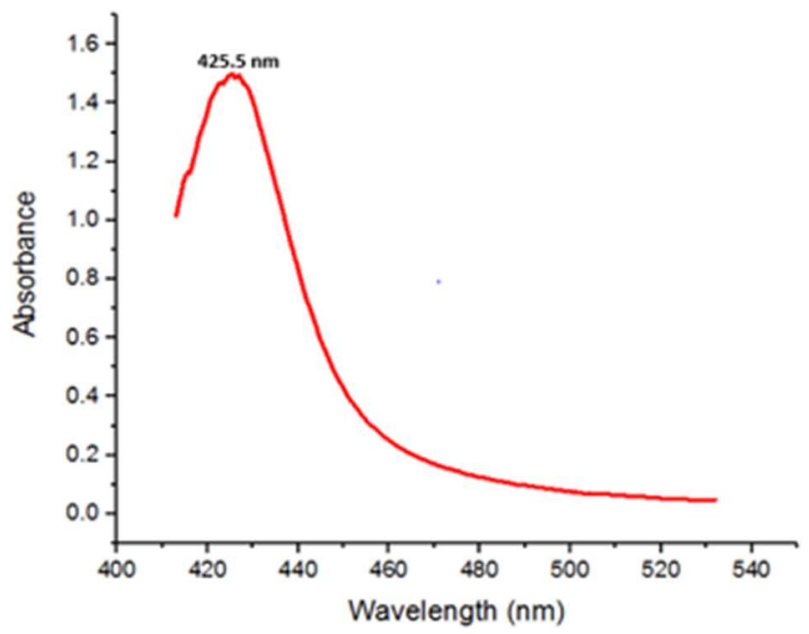

Fig. 5: UV-Vis spectrum of Cu-AgNPs

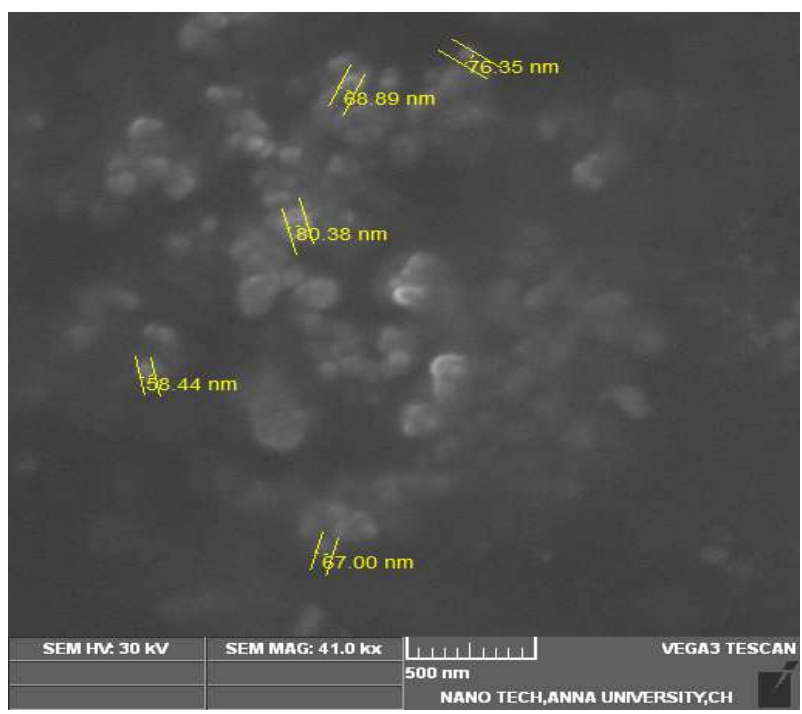

Fig. 6: SEM image of Cu-AgNPs

\section{Scanning electron microscopy (SEM)}

The size and shape of the Cu-AgNPs can be detected by sputter coating the sample on the copper stub and the images of nanoparticles were studied using SEM [17]. From the SEM images, the spherical shape of the $\mathrm{Cu}-\mathrm{AgNPs}$ with size ranging from 50 $\mathrm{nm}$ to $85 \mathrm{~nm}$ was observed (fig. 6).

\section{Energy dispersive X-ray spectroscopy (EDAX)}

The EDAX analysis of Cu-AgNPs confirmed the presence of elemental silver without any contamination (fig. 7). It was found that among all the elements present, silver is found to contain in higher percentage and its weight percentage was found to be $16.54 \%$.

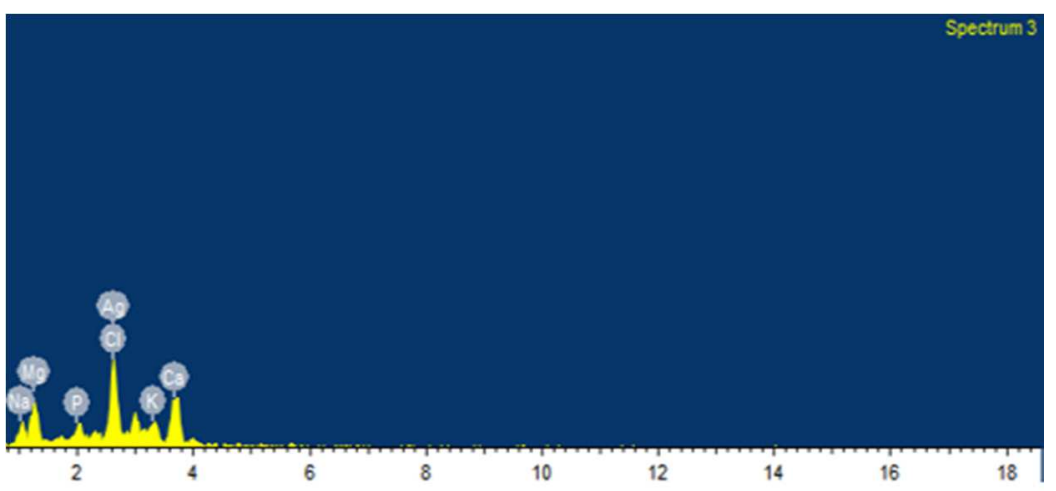

Fig. 7: EDAX spectrum of Cu-AgNPs 


\section{Fourier transform infrared (FTIR) spectroscopy}

From the FTIR analysis, the natural reducing and capping agents of the $\mathrm{Cu}-\mathrm{SE}$ was identified. From fig. 8a and fig. 8b, the functional groups present in the $\mathrm{Cu}-\mathrm{AgNPs}$ and $\mathrm{Cu}-\mathrm{SE}$ was analyzed for the spectra peaks at $3410.15 \mathrm{~cm}^{-1}, 2939.52 \mathrm{~cm}^{-1}, 1080.14 \mathrm{~cm}^{-1}, 879.54$ $\mathrm{cm}^{-1}, 732.95 \mathrm{~cm}^{-1}$ and $2931.80 \mathrm{~cm}^{-1}, 2376.30 \mathrm{~cm}^{-1}, 1087.85 \mathrm{~cm}^{-1}$, $864.11 \mathrm{~cm}^{-1}$. The absorption peak at $3410.15 \mathrm{~cm}^{-1}$ suggests the $0-\mathrm{H}$ stretch, peak at $2939.52 \mathrm{~cm}^{-1}, 2931.80 \mathrm{~cm}^{-1}$ and $732.95 \mathrm{~cm}^{-1}$ represents the saturated hydrocarbon $\mathrm{C}-\mathrm{H}$ stretch, methylene $\mathrm{C}-\mathrm{H}$ stretch and aromatic C-H bend respectively.

Peaks at $864.11 \mathrm{~cm}^{-1}, 879.54 \mathrm{~cm}^{-1}$ represents C-C vibration and 1087.85 $\mathrm{cm}^{-1}, 1080.14 \mathrm{~cm}^{-1}$ is due to primary amine C-N stretch. The hydroxyl group and the $\mathrm{C}-\mathrm{H}$ stretch of alkane and alkene in $\mathrm{Cu}-\mathrm{SE}$ are mainly involved in the reduction of Ag+ions to AgNPs. Also, the presence of carbonyl group of amino acid residues and Aromatic amine residues acts as a capping agent to prevent agglomeration and stabilizes AgNPs [18].
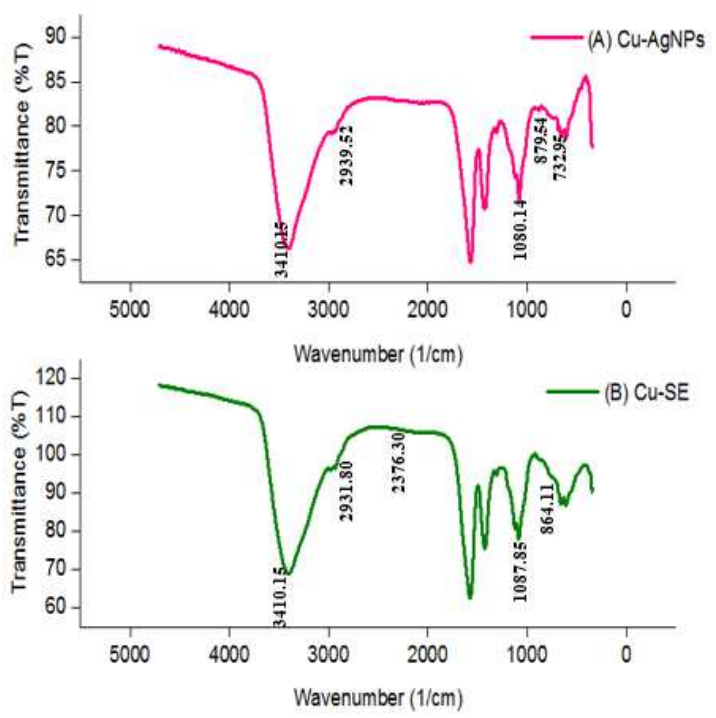

Fig. 8: FTIR peaks showing (A) functional groups of Cu-AgNPs (B) functional groups of Cu-SE

\section{X-ray diffraction (XRD)}

The diffraction peaks at $2 \theta$ values $27.783^{\circ}, 32.196^{\circ}, 46.130^{\circ}$, $67.32^{\circ}, 74.47^{\circ}$ and $76.59^{\circ}$ in the experimental diffractogram obtained through XRD have been identified to be due to the presence of noble metal silver in the sample and the corresponding $h k l$ values are (111), (200), (200), (220), (311) and (311) respectively (fig. 9). All the peaks represent the Facecentered cubic (FCC) structure of the silver element. The average crystalline size ' $\mathrm{D}$ ' of AgNPs was calculated by Debye-Scherrer formula and was found to be $26 \mathrm{~nm}$ and the average lattice constant of AgNPs is $4.5535 \AA$ [19].

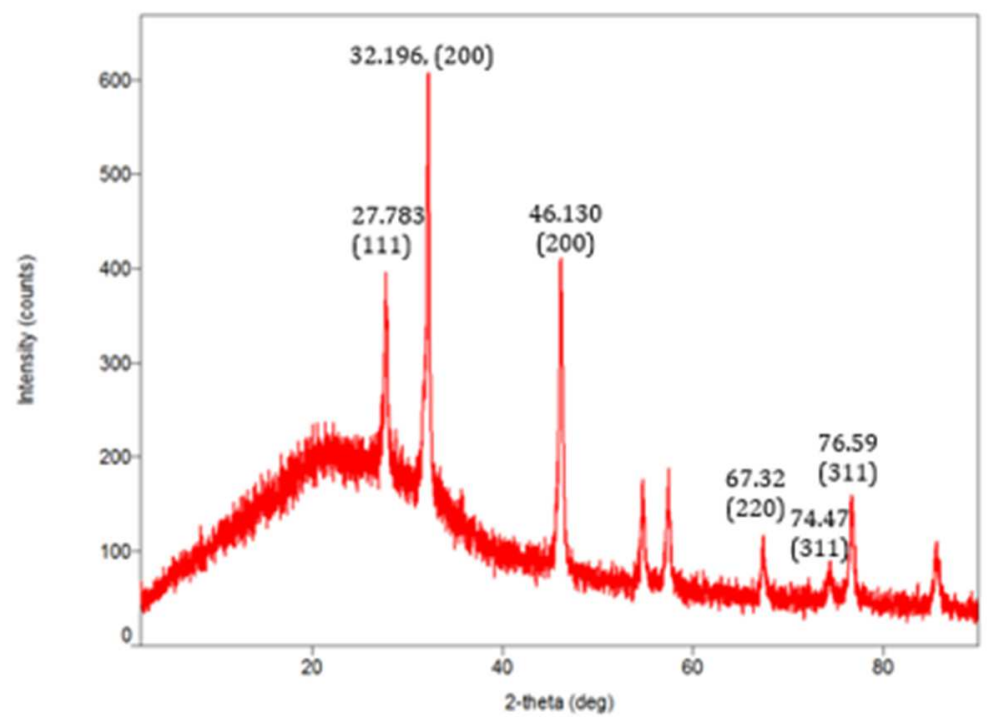

Fig. 9: XRD peaks of Cu-AgNPs

\section{Antibacterial activity}

A comparison of the antimicrobial activity of the $\mathrm{Cu}-\mathrm{SE}$ and $\mathrm{Cu}-$ AgNPs was done to observe the inborn antimicrobial activity of the plant (Cu-SE) and its enhanced efficacy by synthesis of AgNPs (CuAgNPs). In table 1 and table 2, when gram positive strain Bacillus subtilis were tested against $\mathrm{Cu}-\mathrm{SE}$ and $\mathrm{Cu}-\mathrm{AgNPs}$ (fig. 10a, 10b), the diameter of the inhibition zone was higher for Cu-AgNPs ranging 
from $12 \mathrm{~mm}$ to $16 \mathrm{~mm}$ than the Cu-SE which was found to be $11 \mathrm{~mm}$ to $13 \mathrm{~mm}$. Also, when both the samples were tested against gram negative bacteria Escherichia coli (fig. 11a, 11b), enhanced anti- bacterial activity was observed with Cu-AgNPs showing zone inhibition from $11 \mathrm{~mm}$ to $14 \mathrm{~mm}$ when compared to Cu-SE with 10 $\mathrm{mm}$ to $14 \mathrm{~mm}$ diameter inhibition zone.
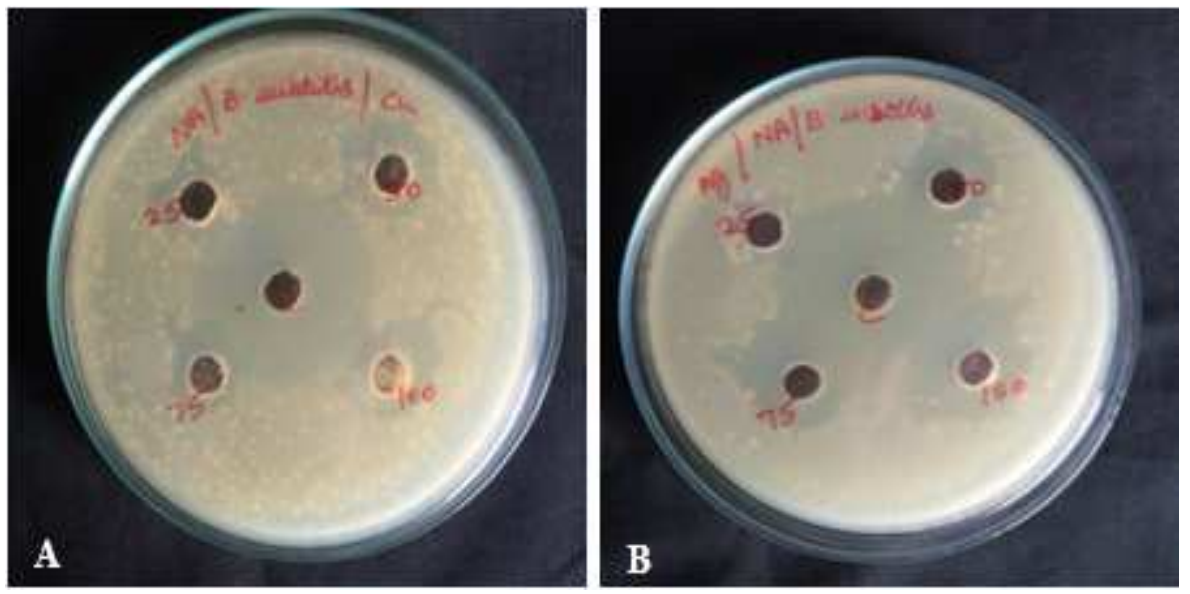

Fig. 10: Antibacterial activity against gram positive B. subtilis when treated with (A) Cu-SE (B) Cu-AgNPs
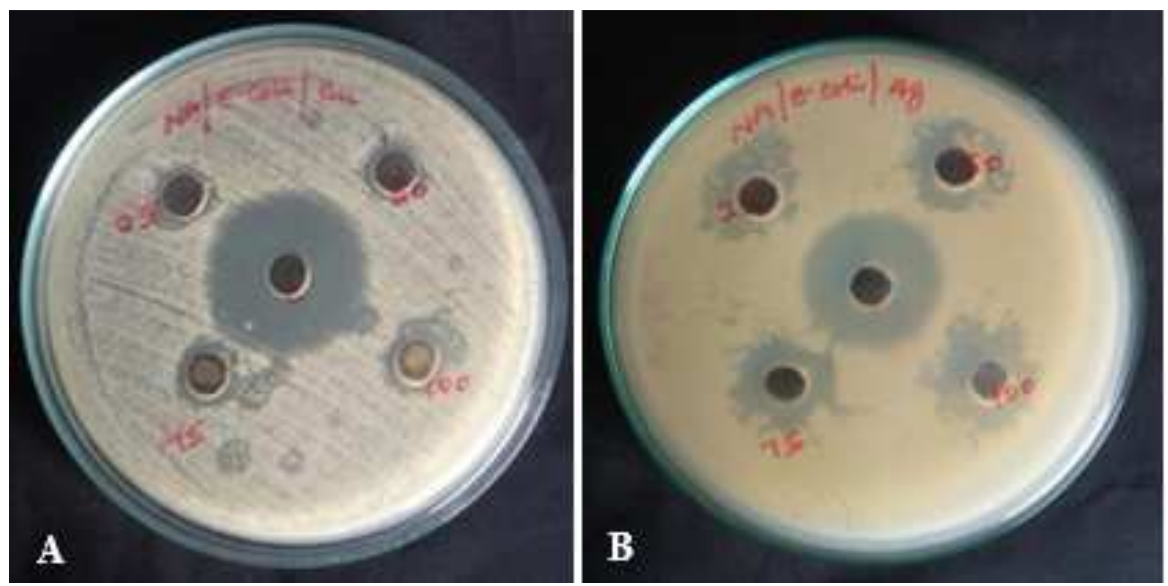

Fig. 11: Antibacterial activity against gram negative $E$. coli when treated with (A) Cu-SE (B) Cu-AgNPs

Table 1: Zone of inhibition (mm) of gram positive B. subtilis by plant extract and AgNPs

\begin{tabular}{llllll}
\hline Inhibition & \multicolumn{2}{l}{ Concentration $(\boldsymbol{\mu g} / \mathbf{m l})$} & & $\mathbf{7 5 0}$ & $\mathbf{1 0 0 0}$ \\
\cline { 2 - 6 } & PC & $\mathbf{2 5 0}$ & $\mathbf{5 0 0}$ & $11 \pm 0.30$ & $13 \pm 0.15$ \\
C. umbellata extract $(\mathrm{mm})$ & $19 \pm 0.20$ & $9 \pm 0.10$ & $11 \pm 0.20$ & $14 \pm 0.25$ & $16 \pm 0.40$ \\
AgNPs $(\mathrm{mm})$ & $19 \pm 0.20$ & $11 \pm 0.25$ & $12 \pm 0.15$ & 15 \\
\hline
\end{tabular}

PC-Positive Control, AgNPs-Silver Nanoparticles, C. umbellata-Caralluma umbellate, $(\mathrm{n}=4$, mean $\pm \mathrm{SD})$

Table 2: Zone of inhibition (mm) of gram negative $E$. coli by plant extract and AgNPs

\begin{tabular}{llllll}
\hline Inhibition & \multicolumn{2}{l}{ Concentration $(\boldsymbol{\mu g} / \mathbf{m l})$} & & $\mathbf{7 5 0}$ & $\mathbf{1 0 0 0}$ \\
\cline { 2 - 6 } & PC & $\mathbf{2 5 0}$ & $\mathbf{5 0 0}$ & $11 \pm 0.25$ & $12 \pm 0.35$ \\
C. umbellata extract $(\mathrm{mm})$ & $18 \pm 0.10$ & $10 \pm 0.30$ & $10 \pm 0.40$ & $12 \pm 0.40$ & $14 \pm 0.10$ \\
AgNPs (mm) & $15 \pm 0.30$ & $11 \pm 0.15$ & $12 \pm 0.10$ & $12 \pm 0.40$ \\
\hline
\end{tabular}

PC-Positive Control, AgNPs-Silver Nanoparticles, C. umbellata-Caralluma umbellata $(\mathrm{n}=4$, mean $\pm \mathrm{SD})$

\section{Antifungal activity}

Table 3 represents the antifungal activity of Aspergillus niger and the inhibition zone. The plant extract showed an inhibition diameter of
$10 \mathrm{~mm}$ for varying concentrations $(250 \mu \mathrm{g} / \mathrm{ml}-1000 \mu \mathrm{g} / \mathrm{ml})$ of the sample. And the AgNPs showed a slight increase in the inhibition diameter from $10 \mathrm{~mm}$ to $11 \mathrm{~mm}$ with an increase in the concentration from $250 \mu \mathrm{g} / \mathrm{ml}$ to $1000 \mu \mathrm{g} / \mathrm{ml}$ (fig. 12a, 12b). 

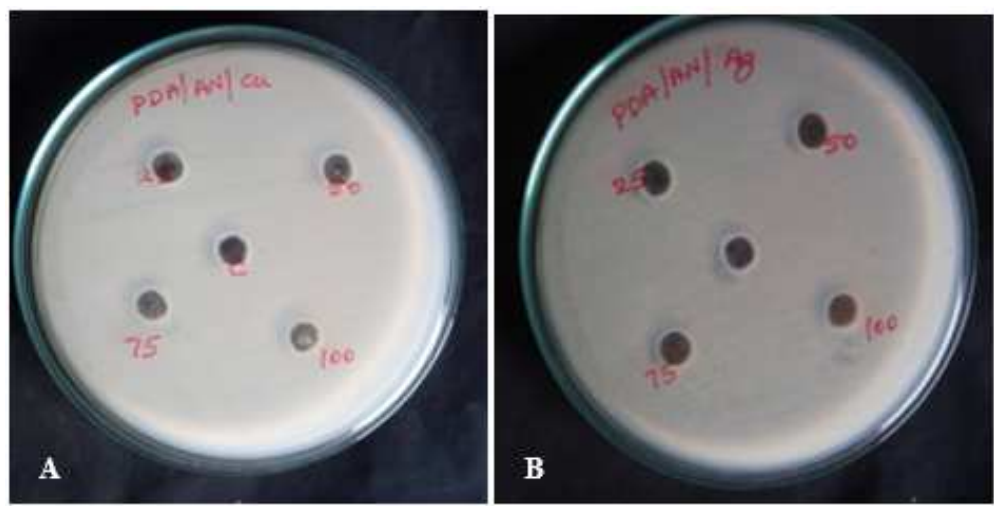

Fig. 12: Antifungal activity against $A$. niger when treated with (A) plant extract (B) AgNPs

Table 3: Zone of inhibition (mm) of $A$. niger by the plant extract and AgNPs

\begin{tabular}{|c|c|c|c|c|c|}
\hline \multirow[t]{2}{*}{ Inhibition } & \multicolumn{5}{|c|}{ Concentration $(\mu \mathrm{g} / \mathrm{ml})$} \\
\hline & PC & 250 & 500 & 750 & 1000 \\
\hline C. umbellata extract (mm) & $10 \pm 0.25$ & $10 \pm 0.20$ & $10 \pm 0.20$ & $10 \pm 0.30$ & $10 \pm 0.35$ \\
\hline AgNPs (mm) & $10 \pm 0.25$ & $10 \pm 0.30$ & $10 \pm 0.30$ & $11 \pm 0.25$ & $11 \pm 0.40$ \\
\hline
\end{tabular}

PC-Positive Control, AgNPs-Silver Nanoparticles, C. umbellata-Caralluma umbellata $(\mathrm{n}=4$, mean $\pm \mathrm{SD}$ )

\section{DISCUSSION}

Under optimized condition $0.55 \mathrm{mmol} \mathrm{AgNO}_{3}$ concentration, $45{ }^{\circ} \mathrm{C}$ and $24 \mathrm{~h}$ of reaction time, the synthesized particles were confirmed as silver in a spherical shape with a size $50 \mathrm{~nm}$ to $90 \mathrm{~nm}$ possessing FCC structure. The AgNPs synthesized showed enhanced inhibition against the tested microbes bacteria and fungus when compared to the $C$. umbellata stem extract. The electrostatic attraction between the positive charge of AgNPs and negative charge of the cell membrane enables $\mathrm{Cu}$-AgNPs to attack the cell membrane thereby, inhibiting the growth of gram positive than gram negative bacteria by its efficacity to penetrate deep into the thick peptidoglycan layer of gram positive bacteria by building reactive oxygen species, causing lysis of cell $[20,21]$ and serving as an antimicrobial agent. In the case of B. subtilis, Cu-AgNPs damages the cellular membranes by losing the membrane integrity thereby, increasing the permeability causing protein dysfunction, increased reactive oxygen species (ROS) in cells [22], lowering the reductase activity and Phag-GFP expression levels leading to cell death [23]. Similarly, the inhibition of E. coli by $\mathrm{Cu}-$ AgNPs begins with the accumulation of envelope protein precursors causing dissipation of the proton motive force and membrane integrity [24] thereby, ceasing the exchange of phosphate ions and this causes an outflow of accumulated phosphate along with succinate, mannitol, proline and glutamate [25]. Hence, the reduced susceptibility of gram positive bacteria to antibiotic [26] has been overcome by treatment with $\mathrm{Cu}$-AgNPs. The inhibitory activity of $\mathrm{Cu}$-AgNPs is higher when compared to $\mathrm{Cu}$-SE where these $\mathrm{Cu}$-AgNPs damages the membrane and forms complexes with bases of DNA followed by inhibition of the normal budding process and cell lysis [16].

\section{CONCLUSION}

The present work suggests that the chosen tribal plant and the synthesized AgNPs acts as wide spectrum inhibitors with good antibacterial and biocidal properties. Also, the Cu-AgNPs synthesized is of affordable and environmentally supporting product. The presence of varied phytochemicals in the plant produces AgNPs in an eco-friendly way which is suitable for targeted drug-delivery with minimal damage to the healthy tissues. Also, the phytochemicals present performs its role as capping agents, hence stabilized AgNPs is produced. The presence of antimicrobial property in C. umbellata as inborn makes the synthesized AgNPs even more effective and as a potent germicide. The antibacterial property of $\mathrm{Cu}-\mathrm{AgNPs}$ can be used as wound healing products, in food storage packages or vessels, textile industry, consumer products, etc. Due to its biocidal properties, $\mathrm{Cu}-\mathrm{AgNPs}$ can be used to destroy plant pathogens thereby preventing rotting of vegetables, fruits and use of artificial fungicides. The synthesized Cu-AgNPs is of low priced and can be further studied for its potent healing properties in the field of nanomedicine.

\section{ACKNOWLEDGEMENT}

The authors would like to thank our mentor and professor, Dr. N. Nagendra Gandhi for his immense support and the staffs of the department of chemical engineering for providing the necessary equipment at the right time.

\section{AUTHORS CONTRIBUTIONS}

All the author have contributed equally.

\section{CONFLICT OF INTERESTS}

\section{Declared none}

\section{REFERENCES}

1. Ahmed S, Ahmad M, Swami BL, Ikram S. A review on plant extract mediated synthesis of silver nanoparticles for antimicrobial applications: a green expertise. J Adv Res 2016;7:17-28.

2. Banjare J. Application of nanotechnology in food technology and targeted drug therapy for prevention of obesity: an overview. J Crit Rev 2016;4:7-11.

3. Galib BM, Mashru M, Jagtap C, Patgiri BJ, Prajapati PK. Therapeutic potentials of metals in ancient India: a review through Charaka Samhita. J Ayurveda Integr Med 2011;2:55-63.

4. Murugesan S, Bhuvaneswari S, Sivamurugan V. Green synthesis, characterization of silver nanoparticles of a marine red alga Spyridia fusiformis and their antibacterial activity. Int J Pharm Pharm Sci 2017;9:192-7.

5. Benn T, Cavanagh B, Hristovski K, Posner JD, Westerhoff P. The realease of Nanosilver from consumer products used in the home. J Environ Qual 2010;39:1875-82.

6. Jegadeeshwari LA, Dharathi N, Lakshmi DV, Kumar EV, Gandhi NN. Tribal plants and their inborn antimicrobial activities. Asian J Pharm Clin Res 2017;10:31-7.

7. Park Y,Hong YN, Weyers A, Kim YS, Linhardt RJ. Polysaccharides and phytochemicals: a natural reservoir for the green synthesis of gold and silver nanoparticles. IET Nanobiotechnol 2011;5:69-78.

8. Chandrappa CP, Chandrasekar N, Govindappa M, Shanbhag C, Singh UK, Masarghal J. Antibacterial activity of synthesized 
silver nanoparticles by Simaroubaglauca against pathogenic bacteria. Int J Curr Pharm Res 2017;9:19-22.

9. Menon S, Agarwal H, Kumar SR, Kumar SV. Green synthesis of silver nanoparticles using medicinal plant Acalypha indica leaf extracts and its application as an antioxidant and antimicrobial agent against foodborne pathogens. Int J Appl Pharm 2017; 9:42-50.

10. Shah W, Patil U, Sharma A. Green synthesis of silver nanoparticles from stem bark extract of Terminalia tomentosa Roxb. (Wight and Arn.). Der Pharma Chem 2014;6:197-202.

11. Karuppusamy S, Pullaiah T. PV-01 diversity and conservation of genus Caralluma (Asclepiadaceae) in peninsular India. National Conference on Forest Biodiversity Resources: Exploitation Conservation and Management; 2006. p. 176-7.

12. Savithramma N, Yugandhar P, Devi PS, Ankanna S, Suhrulatha D, Prasad KS, et al. Documentation of ethnomedicinal information and antimicrobial validation of Thespesia populnea used by Yanadi tribe of Ganugapenta village, Chittoor district, Andhra Pradesh, India. J Int Ethnopharmacol 2017;6:158-69.

13. Jeyakumar JJ, Kamaraj M, Nandagopalan V, Anburaja V, Thiruvengadam M. A study of phytochemical constituents in Caralluma umbellata by Gc-Ms anaylsis. Int J Pharm Sci Invent 2013;2:37-41.

14. Shanmugam G, Ayyavu M, Rao DM, Devarajan T, Subramaniam G. Hepatoprotective effect of Caralluma umbellate against acetaminophen-induced oxidative stress and liver damage in rat. J Pharm Res 2013;6:342-5.

15. Bellamakondi PK, Godavarthi A, Ibrahim M. Anti-hyperglycemic activity of Caralluma umbellata Haw. BioImpacts 2014;4:113-6.

16. Balashanmugam P, Balakumaran MD, Murugan R. Phytogenic synthesis of silver nanoparticles, optimization and evaluation of in vitro antifungal activity against human and plant pathogens. Microbiol Res 2016;192:52-64.
17. Krishnaraj C, Jagan EG, Rajasekar S, Selvakumar P, Kalaichelvan PT, Mohan N. Synthesis of silver nanoparticles using acalypha indica leaf extracts and its antibacterial activity against water borne pathogens. Colloids Surf B 2010;76:50-6.

18. Coates J. Interpretation of infrared spectra, a practical approach. In: Encyclopedia of Analytical Chemistry. Meyers RA. Editor. John Wiley and Sons Ltd; Chichester; 2000.

19. Mehta BK, Chhajlani M, Shrivastava BD. Green synthesis of silver nanoparticles and their characterization by XRD. J Phys Conf Ser 2017;836:1-5.

20. Karthikeyan J, Nila KM, Thooyavan G, Vimalkumar E. Larvicidal and antibacterial efficacy of green synthesized silver nanoparticles using Melia dubia. Int J Pharm Pharm Sci 2014; 6:395-9.

21. Antony E, Sathiavelu M, Arunachalam S. Synthesis of silver nanoparticles from the medicinal plant Bauhinia Acuminata and Biophytum Sensitivum-A comparative study of its biological activities with plant extract. Int J Appl Pharm 2017;9:22-9.

22. Ouay BL, Stellacci F. Antibacterial activity of silver nanoparticles: a surface science insight'. Nano Today 2015; 10:339-54.

23. Hsueh YH, Lin KS, Ke WJ, Hsieh CT, Chiang CL, Tzou DY, et al. The antimicrobial properties of silver nanoparticles in Bacillus subtilis are mediated by released Agtion. PLoS One 2015;10:1-17.

24. Lok CN, Ho CM, Chen R, He QY, Yu WY, Sun H, et al. Proteomic analysis of the mode of antibacterial action of silver nanoparticles. J Proteome Res 2006;5:916-24.

25. Rai M, Yadav A, Gade A. Silver nanoparticles as a new generation of antimicrobials. Biotechnol Adv 2009;27:76-83.

26. Dakal TC, Kumar A, Majumdar RS, Yadav V. Mechanistic basis of antimicrobial actions of silver nanoparticles. Front Microbiol 2016;7:1-17. 